\title{
PORSTITUSI ONLINE DITINJAU DARI PERSPEKTIF HUKUM PIDANA
}

\section{Oleh}

\author{
Maria Karangora ${ }^{1}$, Bambang Pudjiono ${ }^{2}$, Fitri Windradi ${ }^{3}$, Agung Mafazi $^{4}$
}

\begin{abstract}
Abstraksi
Porstitusi adalah suatu bentuk perdagangan yang dilarang dalam hukum nasional Indonesia karena bertentangan dengan norma-norma kehidupan sosial terutama norma kesusilaan dan kepatutan. Perilaku perdagangan kenikmatan ini telah berlangsung sejak lama bahkan dalam relief candi-candi di indonesia ditemukan gambaran bahwa perilaku menjajakan kenikmatan ini telah eksis sejak jaman kerajaan hindu budha di Indonesia. Kini di tengah moderenisasi kehidupan masyarakat, prosesi menjajakan diri telah berubah karakternya dari semula dilakukan secara sembunyi-sembunyi di tepi jalan yang sepi hingga kini masuk kedalam layar mungil sebuah smartphone yang tentu saja di genggam oleh hampir semua anggota masyarakat jaman sekarang. Dengan ditunjang oleh kemudahan akses data dan juga keterbukaan informasi, porstitusi memiliki bentuk baru dimana kini pedagang kenikmatan dapat dengan mudah ditemukan di media-media sosial. Fenomena ini dikenal dengan istilah porstitusi online. Hukum pidana dirasakan perlu merasuk lebih dalam ke sendi-sendi kehidupan masyarakat. Bukan hanya kehidupan sosial tetapi juga kehidupan di dunia maya dimana transaksi-transaksi yang dilarang menampakkan wujudnya, termasuk porstitusi online. Penelitian ini dilangsungkan secara normatif dan diharapkan dapat menjadi masukan serta bahan kajian dalam mengembangkan hukum yang tepat untuk meningkatkan kewaspadaan masyarakat sekaligus menekan pertumbuhan praktek perdagangan kenikmatan yaitu porstitusi online ini.
\end{abstract}

Kata kunci : $\quad$ porstitusi, online, hukum pidana

\section{Pendahuluan}

Kemajuan teknologi informasi telah memberikan banyak keuntungan bagi setiap tingkat lapisan masyarakat di berbagai bidang. Kemajuan teknologi yang

\footnotetext{
Tenaga Ahli Walikota Kediri

Dosen Fakultas Hukum Universitas Kadiri, email : bambang pudhiono@unik-kediri.ac.id

Dosen Fakultas Hukum Universitas Kadiri, email : aidhil_fitri@yahoo.co.id

Dosen Fakultas Hukum Universitas Kadiri, email : agung mafazi@unik-kediri.ac.id
} 
dimaksud adalah keberadaan jaringan internet yang dapat diakses oleh siapa saja dan di mana saja, tetapi kemajuan teknologi yang dapat dinikmati oleh siapa saja ini telah menjelma menjadi peluang untuk melakukan kejahatan yang menguntungkan karena mudahnya akses komunikasi serta data yang lebih cepat dan biaya ringan. Salah satu kejahatan menggunakan fasilitas internet adalah prostitusi. Masalah pelacuran adalah masalah yang rumit, banyak hal terkait di sana. Karena itu, masalah ini perlu mendapat perhatian khusus oleh masyarakat sebagai bagian dari lingkungan sosial.

Prostitusi, bisnis yang identik dengan dunia hitam, adalah salah satu bisnis yang menghasilkan uang dengan sangat cepat. Tidak perlu banyak modal, hanya tubuh jasmani yang secara profesional bersedia dikomersialkan. Itu sebabnya sampai kapan pun bisnis ini tidak akan menemui masa-masa sulit. Pelacuran tidak hanya berdampak pada mereka yang melakukan penawaran dan pengguna layanan sebagai pembeli tetapi juga dampaknya bagi masyarakat luas.

Prostitusi bahkan membahayakan kehidupan rumah tangga yang terjalin hingga dapat mengarah pada tindak pidana kejahatan dan sebagainya. Agama sebagai salah satu pedoman dalam kehidupan benar-benar diabaikan oleh mereka yang terlibat dalam praktik pelacuran dan benar-benar suatu tindakan yang dilarang oleh agama. Prostitusi bukan hanya fenomena individu tetapi menjadi fenomena sosial penyimpangan seksual normal serta agama. Diketahui bahwa tindakan prostitusi di Indonesia telah terjadi sejak jaman kerajaan bahkan jauh sebelum kemerdekaan. Prostitusi di Indonesia adalah salah satu tindakan tercela dan melanggar norma 
kesusilaan, adat istiadat dan agama. Orang-orang akan mengecam dan menganggap tindakan porstitusi ini sebagai tindakan yang memalukan.

Dalam arti lain kata prostitusi berasal dari kata Latin prostituere yang berarti menyerah secara terbuka kepada perzinahan dan sangat dekat artinya dengan persetubuhan. Sedangkan etimologinya berasal dari kata prostare yang artinya berjualan, menjajakan. Jadi pelacuran adalah transaksi antara pelacur dan penggunanya yang memberikan sejumlah uang untuk interaksi seksual (Simandjuntak, 2012). Kegiatan dan praktik pelacuran di Indonesia diuraikan dalam dua bentuk yaitu pelacuran terorganisir dan pelacuran tidak terdaftar. Prostitusi terdaftar dalam menjalankan kegiatannya dilakukan dengan cara para pelacurnya diawasi oleh wakil Departemen Kontrol kepolisian, yang dibantu dan bekerja sama dengan layanan sosial dan layanan kesehatan. Umumnya mereka dilokalisasi di satu area tertentu. Pelacurnya harus diperiksa kesehatannya secara berkala dengan dokter atau petugas kesehatan, dan menerima suntikan dan obat-obatan, sebagai ukuran keselamatan publik.

Seperti yang ditulis oleh Profesor W. A Bonger dalam tulisannya, MaatschappelijkeOorzaken der Prostitute menulis definisi pelacuran adalah fenomena sosial di mana perempuan menjual diri mereka untuk tindakan seksual sebagai mata pencaharian. Menurut definisi ini jelas dinyatakan bahwa ada acara self-selling sebagai profesi atau mata pencaharian sehari-hari dengan melakukan hubungan seksual (Kartono, 2013). 
Sementara itu, pelacuran tidak terdaftar dalam melakukan kegiatannya yaitu mereka yang melakukan pelacuran ilegal baik secara individu maupun kelompok. Tindakannya tidak terorganisir, tempatnya tidak pasti. Dapat ditemukan di mana saja, baik mencari mangsanya sendiri atau melalui broker dan panggilan. Mereka tidak mendaftar dengan pihak berwenang.Sehingga kesehatannya sangat diragukan, karena belum tentu mereka rela memeriksakan kesehatannya ke dokter. Dibandingkan dengan prostitusi online, kegiatan terorganisir terdiri dari pekerja seks komersial, mucikari dan klien (klien) ditambah kemajuan teknologi melalui internet, di mana media lebih aman jika dibandingkan dengan menjajakan di tepi jalanan atau lokalitas. Dengan menggunakan media sosial secara bebas dalam bertransaksi, komunikasi dapat terjadi sebelum bertemu dan bahkan belum tentu saling bertemu langsung antara pelaku pelacuran dengan seseorang yang ingin menggunakan jasanya. Seperti kasus prostitusi online yang merajalela di Indonesia.

Pekerja seks komersial akan mempromosikan diri mereka sendiri melalui media sosial dengan atau tanpa mucikari, pencari kenikmatan kemudian menemukan iklan pekerja seks tersebut lalu terhubung melalui media sosial dan terhubung dengan aplikasi chat seperti Line atau Whatsapp setelah ada kesepakatan maka disepakati tempat dan waktu bertemu. Biasanya klien diminta memberikan down payment atau uang panjer untuk meyakinkan pekerja seks. Dalam iklan yang dipromosikan di media sosial para pekerja seks telah sepenuhnya menentukan layanan yang akan diterima oleh klien. Setelah terhubung melalui media sosial, mereka membuat setting lokasi untuk bertransaksi, biasanya dilaksanakan di hotel / kos. Setelah selesai 
biasanya klien meminta nomor ponsel untuk membuatnya lebih mudah untuk memanggil penjaja seks tersebut kapan saja jika diperlukan. Kementerian Komunikasi dan Informasi Republik Indonesia hingga 2016 telah memblokir 900.000 situs, yang memiliki konten pornografi dan prostitusi berdasarkan Peraturan Menkominfo No.19 / 2014 tentang Penanganan Konten Bermuatan Negatif dan Pornografi.

Perkembangan Ilmu Pengetahuan dan Teknologi (IPTEK) khususnya teknologi informasi dan komunikasi, memang membawa dampak yang besar terhadap kehidupan manusia sekarang ini. Dengan adanya informasi dari bebrbagai kecanggihan alat komunikasi dunia manapun bisa kita ketahui. Namun perkembangan teknologi tersebut tidak selamanya membawa dampak baik. Seiring dengan melesatya teknologi yang semakin canggih sering pula disalahgunakan oleh pihak - pihak tertentu khususnya para pelaku prostitusi dalam menjalankan pekerjaannya dengan menawarkan dirinya melalui media online yang lebih praktis. Pelanggan juga lebih diuntungkan, karena akses mereka akan lebih mudah dan efisien.

Pemanfaatan teknologi informasi, media, dan komunikasi telah mengubah perilaku masyarakat maupun peradaban manusia secara global. Perkembangan teknologi informasi dan komunikasi telah pula menyebabkan hubungan dunia menjadi tanpa batas (borderless). Kemajuan teknologi informasi ini dapat dilihat dengan banyaknya perkembangan dunia cyber namun kemajuan di bidang teknologi informasi ini memeliki banyak dampak. bagaikan pisau yang memiliki dua sisi mata, apabila digunakan untuk kebaikan akan berdampak positif dan apabila digunakan 
pada hal negatif akan berdampak buruk juga. Dengan teknologi paradigma dalam bidang penegakan hukum memandang bahwa pertumbuhan tingkat kejahatan dengan tingkat kemajuan ilmu pengetahuan dan teknologi sebagai suatu hubungan yang positif atau berbanding searah, yaitu bahwa kejahatan akan selalu berkembang sejalan dengan kemajuan yang dicapai dalam bidang ilmu yang berkembang seiring dengan pengetahuan dan teknologi. Salah satu kejahatan yang berkembang seiring dengan kemajuan teknologi yaitu kejahatan prostitusi online melalui media sosial. Terbongkarnya beberapa kasus prostitusi online yang diberitakan secara estafet oleh berbagai media di Indonesia, semuanya memiliki kesamaan dalam modus operasinya. Para pelaku memasarkan diri dan perempuan yang dijualnya melalui internet, baik dengan menggunakan website maupun jejaring sosial seperti Facebook, Twitter, Blackberry Messenger, dan sebagainya. Berbeda dengan prostitusi lainnya yang membutuhkan tempat tertentu atau lokalisasi untuk 'menjajakan' dirinya, keberadaan prostitusi online sepertinya lebih sulit tersentuh dan prakteknya nyaris tidak terlihat karena dilakukan dengan menggunakan media sosial. Melalui sosial media, para pelanggan tidak perlu lagi datang ke lokalisasi atau ke tempat-tempat para PSK ini biasa 'mangkal'. Sebaliknya, para PSK ini yang akan langsung mendatangi mereka tanpa perlu mengetuk pintu rumah, karena foto-foto mereka kini bisa dilihat dengan mudah melalui handphone yang saat ini sudah dimiliki oleh hampir seluruh lapisan masyarakat di Indonesia. Dengan adanya fasilitas chatting, transaksi dan perkenalanpun bisa dilakukan tanpa harus bertatap muka. 
Setelah mendapatkan kesepakatan, para pelaku dan pelanggan bisa bertemu secara langsung di suatu tempat paling rahasia yang disepakati oleh mereka bersama. Semua proses tersebut bisa dilakukan dengan cepat, mudah, dan nyaris tanpa meninggalkan 'jejak' apapun. Untuk melacak keberadaan prostitusi seperti ini memang cukup sulit. Karena selain jumlahnya yang sangat banyak, keberadaan mereka juga tersebar entah dimana. Di dunia maya, setiap orang bisa menyamar menjadi orang lain, memakai nama dan alamat palsu.

Bila lokalisasi atau rumah bordir bisa digrebek atau ditutup oleh aparat dan masyarakat, tapi akun sosial media yang dimiliki para PSK maupun mucikari online ini sulit sekali dihentikan. Karena bila satu akun ditutup atau diblokir, dengan mudah mereka bisa membuat akun lainnya dengan nama dan tampilan baru tanpa mengeluarkan biaya sama sekali. Istilahnya, diblokir satu tumbuh seribu. Selain itu, negara juga tidak bisa asal memblokir akun-akun bermuatan pornografi. Untuk pemblokiran akun-akun tersebut harus meminta izin pada facebook dan twitter. Mendefinisikan pelacuran sebagai transaksi bisnis yang disepakati oleh pihak yang terlibat sebagai sesuatu yang bersifat kontrak jangka pendek yang memungkinkan satu orang atau lebih mendapatkan kepuasan seks dengan metode yang beraneka ragam. Senada dengan hal tersebut, Supratiknya (1995: 97) menyatakan bahwa prostitusi atau pelacuran adalah memberikan layanan hubungan seksual demi imbalan uang. Dalam konteks Indonesia, prostitusi telah berlangsung lama bahkan sejak zaman Mataram. 
Praktik prostitusi pada masa itu dilakukan dengan cara penyerahan perempuan sebagai upeti dan menjadi barang dagangan. Saat ini prostitusi telah berkembang dengan manajemen modern, baik yang dilakukan di rumah - rumah bordil maupun di media sosial. Penyalahgunaan media teknologi informasi ini untuk kejahatan eksploitasi diatur dalam Pasal 27 ayat 1 yang berisi setiap orang yang dengan sengaja dan tanpa hak mendistribusikan atau mentransmisikan membuat dapat diaksesnya informasi elektronik dokunmen elektronik yang memiliki muatan dalam melanggar kesusilaan dan 52 Undang - Undang No.11 tahun 2008 tentang Informasi dan Transaksi Elektronik. Sebenarnya perdagangan manusia bukanlah hal yang baru, namun beberapa tahun belakangan ini masalah ini mulai muncul kepermukaan dan menjadi perhatian khalayak.

\section{Rumusan Masalah}

Pemerintah Indonesia telah memblokir situs web dengan konten transaksi prostitusi online sebanyak 900.000 situs yang memiliki konten porno dan prostitusi, tetapi pertumbuhan situs porno bukannya dapat dikurangi alih-alih malah menimbulkan masalah baru. Situs-situs tersebut tumbuh dua kali lipat dari jumlah yang dapat dengan mudah diakses oleh pengguna internet sehingga konten situs yang menawarkan pekerja seks masih terus tumbuh dalam berbagai mode untuk mendapatkan pelanggan. Pelacuran online yang terus berkembang membawa dampak negatif dari Negara Indonesia, antara lain, merusak moral bangsa, terutama bagi generasi penerus. 
Mereka adalah generasi penerus bangsa sehingga dapat mengancam kehidupan bangsa dan bangsa di masa depan. Menurunnya nilai-nilai Pancasila sebagai ideologi bangsa yang menjadi dasar negara Indonesia. Nilai-nilai agama, moral, dan sosial akan terpinggirkan dan itu hanya akan meninggalkan budaya liberalisme, kebebasan yang merusak tatanan sosial. Prostitusi dapat dimanfaatkan oleh orang asing untuk merusak keamanan nasional, memaksakan identitas bangsa Indonesia yang mulia dengan semangat yang mulia dan menjunjung tinggi nilai-nilai budaya timur dan agama disamping itu prostitusi Online dapat menyebabkan dan menyebarkan penyakit kelamin dan kulit. Pelacuran online adalah kejahatan dan oleh karena itu diperlukan hukum pidana.

Kehadiran hukum pidana dalam masyarakat dimaksudkan untuk memberikan rasa aman kepada individu dan kelompok dalam masyarakat dalam menjalankan aktivitas sehari-hari. Perasaan aman berarti perasaan tenang, tanpa kekhawatiran akan ancaman atau tindakan yang dapat membahayakan individu dalam masyarakat..Kerugian yang dimaksud tidak hanya terkait dengan kerugian seperti yang kita pahami secara sipil, tetapi juga termasuk kerugian bagi jiwa dan tubuh. Tubuh dalam hal ini termasuk tubuh yang juga berhubungan dengan kehidupan seseorang, jiwa dalam hal ini termasuk perasaan atau keadaan psikis (Ilyas, 2012).

Penulis melakukan studi kebijakan hukum pidana dalam pemberantasan prostitusi online dengan memperhatikan aturan perundang-undangan tentang prostitusi online di Indonesia, faktor-faktor yang menyebabkan maraknya prostitusi 
online di Indonesia dan memberikan masukan melalui kajian kebijakan hukum pidana. Dalam pemberantasan kejahatan prostitusi online di Indonesia. Berdasarkan atas pendahuluan dan latar belakang sebagaimana diatas, maka dirumuskanlah butirbutir rumusan masalaah berikut ini :

1. Bagaimana pengaturan penegakan hukum untuk prostitusi online yang marak di Indonesia?

2. Faktor-faktor apa yang menyebabkan menjamurnya prostitusi online di Indonesia?

3. Apa kebijakan hukum pidana dalam memberantas kejahatan prostitusi online di Indonesia?

\section{Tujuan Studi}

Penelitian ini bertujuan untuk mengetahui kebijakan hukum pidana dalam memberantas kejahatan prostitusi online di Indonesia. Secara khusus tujuan dari penelitian ini adalah sebagai berikut di bawah ini:

3.1. Mendeskripsikan penegakan hukum terhadap prostitusi online yang marak di Indonesia

3.2. Mencari dan mendeskripsikan faktor-faktor yang mengarah pada menjamurnya prostitusi online di Indonesia

3.3. Mencari dan mendeskripsikan upaya untuk memberantas prostitusi online di Indonesia melalui kebijakan hukum non pidana.

\section{Metode penelitian}


Berdasarkan rumusan masalah di atas, diketahui bahwa salah satu isu utama dalam penelitian ini adalah kebijakan hukum pidana, terutama implementasi ketentuan dalam merumuskan tindak pidana mengenai prostitusi online. Oleh karena itu, pendekatan yang digunakan oleh penulis adalah pendekatan yang memprioritaskan kebijakan. Tujuan utama dari penelitian ini adalah ketentuan perundang-undangan dalam merumuskan sanksi pidana terhadap prostitusi online, sehingga pendekatan utamanya adalah pendekatan yuridis normatif.

Disamping itu didukung pula oleh pendekatan yuridis sosiologis. Penelitian menggunakan pendekatan yuridis sosiologis untuk dapat mengungkap dan mendapatkan rincian objek penelitian dan sumber daya, serta bagaimana implementasi hukum di masyarakat berdasarkan aturan prostitusi online di Indonesia. Penulis menggunakan pendekatan perundang-undangan yang dilakukan dengan mencari data faktual yang ada dalam undang-undang sebagai dasar untuk membantu penulis dalam menganalisis (Amiruddin, 2012).

Penelitian kepustakaan meliputi materi pertama hukum primer dalam bentuk: Konstitusi 1945, Kitab Undang-Undang Hukum Pidana. Kedua, bahan sekunder adalah bahan yang memberikan penjelasan tentang bahan primer dan dapat membantu menganalisis dan memahami bahan hukum primer, seperti karya ilmiah. Dan bahan hukum Tersier Ketiga adalah bahan yang memberikan informasi tentang bahan hukum primer dan bahan hukum sekunder, seperti artikel dan majalah. Setelah semua data dikumpulkan, itu akan dianalisis dalam perspektif deskriptif, dimaksudkan untuk memberikan deskripsi yang jelas, sistematis, obyektif 
dan kritis yang disajikan dalam hukum positif mengenai fakta-fakta yang normatif atau empiris tentang masalah yang dibahas, dengan mencoba menyajikan materi yang relevan dan dukungan (Suzanalisa, 2012).

\section{Temuan}

\subsection{Pengaturan penegakan hukum tentang prostitusi online lazim di Indonesia}

Kemajuan teknologi informasi melalui internet telah menciptakan peluang bagi pekerja seks, mucikari dan klien untuk menggunakannya dan mereka dapat merasa lebih aman untuk mempercepat proses bisnis mereka dan sekaligus mengamankan tindakan mereka dari petugas, terutama bagi pekerja seks komersialnya, mereka tidak perlu lagi menjajakan diri di tepi jalan. Hal ini ditunjang oleh semakin beragamnya situs pelacuran online, dengan keberadaan media yang satu ini, mereka bisa lebih leluasa dalam bertransaksi, tidak perlu bertemu langsung antara pelaku pelacuran dengan orang yang ingin menggunakan layanannya.

Sehingga prostitusi online menjadi fenomena sosial, sistemnya terletak pada faktor-faktor kondisional, terutama sifat biologis pria dan wanita dan hubungan dengan berbagai aspek kehidupan manusia yang kompleks, sehingga mustahil untuk dihilangkan sama sekali. Jadi, berbagai upaya dan tindakan untuk mengatasi masalah ini targetnya tidak sampai pada penghancuran total yang tentu saja tidak mungkin, 
tetapi arah untuk membendung penyebaran dan mencegah berbagai konsekuensi negatif yang mungkin timbul. (Anwar \& Andang, 2010).

Sebagaimana diatur dalam UUD 1945 sebagai dasar Negara Indonesia dalam Pasal $28 \mathrm{~J}$ ayat (1): Setiap orang harus menghormati hak asasi manusia orang lain dalam tatanan kehidupan masyarakat, bangsa dan negara dan Pasal 28 huruf $\mathrm{J}$ ayat (2) UUD 1945 bahwa dalam melaksanakan Hak dan kebebasan, setiap orang harus tunduk pada pembatasan yang ditetapkan oleh hukum dengan satu-satunya tujuan untuk memastikan pengakuan dan penghormatan terhadap hak-hak kebebasan orang lain dan untuk memenuhi tuntutan yang adil sesuai dengan pertimbangan moral, agama, dan keamanan.

Dengan prostitusi online yang telah menimbulkan dampak negatif merusak moral bangsa, terutama generasi penerus bangsa sehingga dapat mengancam kehidupan bangsa dan Negara di masa depan. Penurunan nilai-nilai Pancasila sebagai ideologi bangsa adalah dasar berdirinya Negara Indonesia. Nilai-nilai agama, moral, dan sosial akan terpinggirkan, dan hanya akan ditinggalkan budaya liberalisme, pelacuran dapat dieksploitasi oleh orang luar untuk merusak keamanan nasional, memaksakan identitas bangsa Indonesia yang mulia dengan luhur dan menjunjung tinggi nilai-nilai budaya timur dan agama dan prostitusi Online dapat menyebabkan dan menyebarkan penyakit kelamin dan kulit karenanya perlu pengaturan dari Pemerintah Indonesia

Berdasarkan pertimbangan ini, Pemerintah Indonesia telah memiliki undangundang dalam penegakan hukum terhadap prostitusi online yang merajalela di 
Indonesia, yaitu KUHP, Undang-Undang Republik Indonesia Nomor 39 Tahun 1999 tentang Hak Asasi Manusia, Undang-Undang Republik Indonesia Nomor 21 tahun 2007 Tentang Pemberantasan Tindak Pidana Perdagangan Orang, Undang-Undang RI No.44 tahun 2008 tentang Pornografi, Undang-Undang Republik Indonesia Nomor 19 Tahun 2016 tentang Perubahan atas Undang-Undang Nomor 14 Tahun 2008 tentang Informasi dan Transaksi Elektronik.

Dalam KUHP, ada 3 (tiga) Pasal yang berkaitan dengan prostitusi yang memberikan sanksi lebih jelas kepada pelaku kejahatan prostitusi yang secara penuh menyatakan bahwa:

Pasal 296 menetapkan bahwa "Siapa pun yang dengan sengaja menghubungkan atau memfasilitasi tindakan cabul oleh orang lain, dan menjadikannya pencarian atau kebiasaan, dapat dihukum dengan hukuman penjara maksimum satu tahun dan empat bulan atau denda paling banyak seribu rupiah"

Pasal 297 KUHP menyatakan bahwa "Perdagangan perempuan dan perdagangan anak laki-laki yang belum cukup umur, terancam hukuman penjara hingga enam tahun"

Dan Pasal 506 yang menyatakan bahwa "Barangsiapa yang menarik keuntungan dari tindakan cabul seorang wanita dan menjadikannya sebagai mata pencaharian, diancam dengan pidana kurungan maksimal satu tahun".

Investigasi lebih lanjut dari Undang-Undang Nomor 39 Tahun 1999 tentang Hak Asasi Manusia yang menguraikan bahwa:

Pasal 23 menyatakan bahwa: 
1. Setiap orang bebas memilih dan memiliki kepercayaan politik.

2. Setiap orang bebas memiliki, mengeluarkan, dan menyebarluaskan opini sesuai dengan pendapatnya hati nurani, secara lisan dan / atau tulisan melalui media cetak atau elektronik dengan mengamati nilai-nilai agama, moral, ketertiban, kepentingan umum dan integritas negara.

Pasal 73 menyatakan bahwa:

"Hak dan kebebasan yang diatur dalam Undang-undang ini dapat dibatasi hanya oleh dan di bawah hukum, hanya untuk memastikan pengakuan dan penghormatan terhadap hak asasi manusia dan kebebasan mendasar orang lain, moral, ketertiban umum, dan kepentingan bangsa"

Kejahatan prostitusi online adalah tindakan perdagangan orang, sehingga melanggar Undang-Undang Republik Indonesia Nomor 21 Tahun 2007 tentang Pemberantasan Kejahatan Perdagangan Orang. Perdagangan orang yang dimaksud dalam artikel ini adalah tindakan merekrut, mengangkut, melindungi, mengirim, mentransfer, atau menerima seseorang dengan ancaman kekerasan, penggunaan kekuatan, penculikan, penangkapan, pemalsuan, penipuan, penyalahgunaan kekuasaan atau rentan. posisi, ikatan hutang atau pembayaran atau tunjangan, Dapatkan persetujuan dari orang lain tersebut, baik yang dilakukan di dalam Negara atau di antara Negara-negara, untuk tujuan eksploitasi atau eksploitasi.Ketentuan sanksi bervariasi, yaitu penjara mulai dari minimal tiga tahun hingga seumur hidup dan denda mulai dari minimum Rp. 120.000.000, - 
(seratus dua puluh juta rupiah) hingga Rp. 5.000.000.000, - (lima milyar rupiah), tergantung pada kategori tindakan sebagaimana diatur dalam Pasal 2 UndangUndang Republik Indonesia Nomor 21 Tahun 2007 tentang Pemberantasan Perdagangan Orang Orang menyatakan sebagai berikut:

1. "Setiap orang yang mempekerjakan, mengangkut, melindungi, mengirim, mentransfer, atau menerima orang dengan ancaman kekerasan, penggunaan kekerasan, penculikan, penangkapan, pemalsuan, penipuan, penyalahgunaan kekuasaan atau posisi rentan, ikatan hutang atau pembayaran atau manfaat Persetujuan dari orang yang mengendalikan orang lain dengan maksud untuk mengeksploitasi orang tersebut di wilayah Republik Indonesia dikenai hukuman penjara minimum 3 (tiga) tahun dan maksimal 15 (lima belas) tahun dan denda paling sedikit Rp120.000.000, 00 (seratus dua puluh juta rupiah) dan paling banyak Rp600.000.000,00 (enam ratus juta rupiah)”.

2. "Jika tindakan sebagaimana dimaksud pada ayat (1) mengakibatkan eksploitasi terhadap orang, maka pelaku akan dihukum dengan hukuman yang sama sebagaimana dimaksud pada ayat (1)”

Unsur-unsur pidana yang terkandung dalam Undang-undang ini adalah setiap orang yang melakukan perekrutan, transportasi, tempat tinggal, pemindahan, pemindahan atau penerimaan orang-orang di bawah ancaman kekerasan, penggunaan kekuatan, penculikan, penangkapan, pemalsuan, penipuan, penyalahgunaan kekuasaan atau rentan. posisi, ikatan hutang atau pembayaran atau tunjangan, 
sehingga mendapatkan persetujuan dari orang lain. Selanjutnya, tindakan yang disebutkan di atas harus memiliki tujuan untuk mengeksploitasi (perhatikan ketentuan pasal 2, ayat 1) atau mengakibatkan eksploitasi (perhatikan ketentuan pasal 2, ayat 2).

Konten yang ditawarkan berdasarkan kriteria, sifat, foto pekerja seks dan layanan prostitusi di situs prostitusi online juga telah melanggar Undang-Undang RI No.44 Tahun 2008 tentang Pornografi yang lebih lengkap tercantum dalam Pasal 4, 7 sebagai berikut:

\section{Pasal 4}

1. "Setiap orang dilarang memproduksi, membuat, mereproduksi, menyalin, mendistribusikan, menyiarkan, mengimpor, mengekspor, menawarkan, menjual, menyewakan, atau menyediakan pornografi yang secara eksplisit mengandung:

a. Persetubuhan / koitus, termasuk koitus yang terdistorsi;

b. Kekerasan seksual;

c. Masturbasi;

d. Ketelanjangan;

e. alat kelamin; atau

f. Pornografi anak-anak.”

2. "Setiap orang dilarang memberikan layanan pornografi yang:

a. Menampilkan ketelanjangan secara eksplisit

b. Secara eksplisit menghadirkan genitalia;

c. Mengeksploitasi atau memamerkan aktivitas seksual; atau 
d. Menawarkan atau mengiklankan, langsung atau tidak langsung, layanan seksual.

\section{Pasal 7}

"Setiap orang dilarang mendanai atau memfasilitasi tindakan sebagaimana dimaksud dalam Pasal 4. Pasal 29 sebagai berikut, "Setiap orang yang memproduksi, mereproduksi, mereproduksi, mendistribusikan, menyiarkan, mengimpor, mengekspor, menawarkan, menyewakan, atau menyediakan pornografi sebagaimana dimaksud dalam Pasal 4 ayat (1) dikenai hukuman penjara paling sedikit 6 (enam) bulan dan 12 (dua belas) tahun dan / atau denda paling sedikit Rp.250.000.000,00 (dua ratus lima puluh juta rupiah) dan paling banyak Rp. 6.000.000.000,00 (enam miliar rupiah).”

\section{Pasal 30}

"Setiap orang yang menyediakan layanan pornografi sebagaimana dimaksud dalam Pasal 4 ayat (2) dikenai hukuman penjara paling sedikit 6 (enam) bulan dan paling lama 6 (enam) tahun dan / atau denda paling sedikit Rp. 250.000.000,00 (dua ratus lima puluh juta rupiah) dan paling banyak Rp. 3.000.000.000,00 (tiga miliar rupiah).”

Kejahatan prostitusi online lebih lanjut melanggar Undang-Undang Republik Indonesia Nomor 19 Tahun 2016 tentang Perubahan Undang-Undang Nomor 14 Tahun 2008 tentang Informasi dan Transaksi Elektronik. Undang-Undang Republik Indonesia Nomor 19 Tahun 2016 merupakan amandemen UndangUndang Nomor 14 Tahun 2008 tentang Informasi dan Transaksi Elektronik untuk menjamin pengakuan dan penghormatan terhadap hak-hak dan kebebasan orang lain dan untuk memenuhi permintaan yang adil sesuai dengan pertimbangan 
keamanan dan ketertiban umum dalam suatu masyarakat Perubahan demokratis perlu dilakukan terhadap Undang-Undang Nomor 11 Tahun 2008 tentang Informasi dan Transaksi Elektronik untuk mewujudkan keadilan, ketertiban umum, dan kepastian hukum.

Sebagaimana diatur dalam Pasal 27 ayat (1) UU Nomor 19 Tahun 2016 tentang Perubahan UU Nomor 11 Tahun 2008, berbunyi. Setiap Orang dengan sengaja dan tanpa hak untuk mendistribusikan dan / atau mengirimkan dan / atau membuat Informasi Elektronik yang dapat diakses dan / atau Dokumen Elektronik yang memiliki konten yang melanggar moralitas dengan hukuman pidana yang diatur dalam Pasal 45 ayat (1) menyatakan bahwa Setiap Orang yang dengan sengaja dan Tanpa hak untuk mendistribusikan dan / atau mentransmisikan dan / atau membuat Informasi Elektronik yang dapat diakses dan / atau Dokumen Elektronik yang memiliki konten melanggar moralitas sebagaimana dimaksud dalam Pasal 27 ayat (1) dikenakan pidana penjara paling lama 6 (enam) tahun dan / atau denda paling banyak Rp1.000.000.000.000,00 (satu miliar rupiah).

\subsection{Faktor yang mengarah pada meluasnya prostitusi online di Indonesia}

Pelacuran online adalah praktik pelacuran dengan menggunakan internet atau media online sebagai sarana komunikasi bagi para pekerja seks dan yang ingin menggunakan layanannya di mana pekerja seks tidak perlu menunggu di pinggir jalan dengan menggunakan internet sebagai sarana penghubung antara PSK dengan yang ingin menggunakan jasanya. Jadi internet hanya sebagai sarana pendukung atau penghubung saja. Perkembangan porstitusi online diawali dan 
didukung pula oleh perkembangan media sosial dan pengguna aplikasi obrolan online yang juga sangat pesat. Faktor-faktor yang menyebabkan seseorang menjadi profesi pekerja seks melalui media online sebagai berikut:

1. Faktor Moral atau Moral, terdiri dari

a. Faktor moral yang rendah, kesalehan seseorang terhadap ajaran agama seseorang.

b. Memahami pentingnya pendidikan dalam keluarga sehingga dapat mempengaruhi pola pikir

2. Faktor-faktor ekonomi

Tingkat kemiskinan didukung oleh keinginan untuk menjalani kehidupan mewah tanpa harus bekerja keras, tidak merasakan kemampuan, keterampilan khusus, tingkat pendidikan yang rendah sehingga berpikir semuanya telah dilakukan sehingga pekerja seks akan dikejar.

3. Faktor Sosiologis

a. Undangan teman-temannya sendiri yang sudah terjun ke dunia prostitusi

b. Pengalaman dan pendidikan mereka sangat minim, mereka akhirnya mudah dibujuk dan terkena tipu daya dari pria. Apalagi dengan janji pekerjaan terhormat dengan gaji tinggi yang akhirnya terjebak ke tempat-tempat pelacuran.

4. Faktor psikologi 
Pengalaman hidup sejak kecil serta yang ditemui setelah dewasa dari keluarga dan lingkungan seperti kekerasan seksual, perceraian orang tua, kegagalan dalam perkawinan, digabungkan, menyebabkan luka jiwa sehingga pelacuran sebagai pelarian untuk menikmati kesenangan dan obat melawan luka-luka jiwa.

5. Faktor kemalasan

Faktor kemalasan biasanya disebabkan oleh psikis dan mental yang rendah, tidak memiliki norma agama dan memiliki wajah kehidupan. Hanya dengan modal fisik, kecantikan jadi mudah mengumpulkan uang.

6. Faktor Biologis

Adanya nafsu seks yang abnormal, tidak terintegrasi dalam kepribadian yang tidak puas dengan hubungan seks dengan satu istri / suami.

7. Faktor Pendukung

Kemajuan teknologi informasi ditandai dengan penggunaan internet dan ponsel yang telah bermigrasi sebagai android sehingga memudahkan akses internet tanpa harus menggunakan komputer untuk membuat seseorang dengan mudah dapat menangani pelacuran.

Hasil penelitian menemukan proliferasi prostitusi online lebih disukai karena faktor utama adalah:

1. Penutupan pelokalan pelacuran di daerah

2. Adanya kebijakan yang dikeluarkan oleh pemerintah daerah terkait dengan pelokalan pelacuran di Indonesia dalam mendukung program Pemerintah 
yang bebas pelokalan pelacuran pada tahun 2019 seperti pelokalan "Gang Dolly" di Kota Surabaya yang dijuluki sebagai Pelokalan prostitusi tertua dan terbesar di Indonesia. Indonesia, Lokalisasi "Kramat Tunggak", Lokalisasi "Kalijodo" di Kota Jakarta, Lokalisasi "Saritem" di Bandung, Lokalisasai "Used Joboan" di Kota Purbalingga diikuti oleh beberapa lokalisasi lain di kota-kota Indonesia seperti Jambi, Yogya, Samarinda, seperti yang disampaikan oleh Kementerian Sosial di Indonesia yang telah menutup lokalisasi sebanyak 39 dari total target 139 dan Indonesia. Meskipun pemerintah Indonesia bekerja sama dengan Pemerintah Daerah di lokasi lokalisasi telah membuat kebijakan memberikan pesangon dan pekerjaan bagi pekerja seks dan mucikari tetapi ini tidak menghentikan prostitusi, melalui media sosial digunakan sebagai alat transaksi prostitusi dengan aman dan mudah untuk mendapatkan klien

\section{Untuk Pekerja Seks}

a. Harga jualnya lebih mahal

b. Tawaran yang diberikan di situs prostitusi online lebih mahal daripada di jalanan atau di lokalisasi dan tidak butuh waktu lama untuk mendapatkan persetujuan. Jadi, itu memberi manfaat bagi pekerja seks.

c. Lebih aman

d. Melalui media prostitusi online, keuntungan lain yang didapat adalah keamanan pekerja seks, karena jelas di mana tempat pertemuan itu, dan semua perjanjian telah dilaksanakan oleh mucikari dan pelanggan dengan lebih patuh 
berdasarkan penelitian yang diperoleh rata-rata pelanggan dari prostitusi online adalah orang-orang yang memiliki pendidikan dan keuangan yang lebih baik daripada pelacuran di jalanan atau lokalisasi.

e. Tidak berisiko berurusan dengan hukum

f. Prostitusi di jalanan lebih berisiko dari penggerebekan oleh penegakan hukum di kedua hotel sehingga pekerja seks dan pelanggan merasa tidak nyaman berbanding terbalik secara proporsional melalui prosthesis online, semuanya diatur dengan baik dan memberikan kenyamanan bagi pekerja seks.

\section{Germo}

a. Pemrosesan transaksi yang lebih cepat

b. Melalui media sosial prostitusi ditawarkan lebih cepat dan tidak memerlukan waktu lama dalam menemukan kesepakatan dan pembayaran cepat serta cara pekerjaan dimulai, pekerja seks komersial akan mempromosikan diri mereka melalui media sosial oleh mucikari. Pelanggan menemukan iklan pekerja seks kemudian dihubungkan melalui media sosial dan dalam menghubungkan dengan BBM atau WhatsApp setelah ada kesepakatan kata. Mereka bisa saling bertemu. Biasanya jika proses sebelum transaksi pelanggan diharapkan memberikan uang muka terlebih dahulu untuk meyakinkan seks

c. pekerja. Dalam iklan yang dipromosikan di media sosial, pekerja seks telah sepenuhnya menentukan layanan yang akan diterima oleh pelanggan. Setelah terhubung melalui BBM atau WhatsApp, itu akan menentukan di mana implementasinya. Setelah selesai biasanya seorang hidung belang akan segera 
meminta nomor ponsel untuk membuatnya lebih mudah untuk memanggilnya kembali kapan saja jika diperlukan.

d. Lebih banyak keuntungan dalam hal pembagian pendapatan

e. Harga jual atau penawaran yang disediakan melalui prostitusi online lebih mahal daripada prostitusi jalanan / di lokalisasi, jadi ini akan mempengaruhi keuntungan yang didapat oleh mucikari.

f. Lebih mudah memonitor keamanan pekerja seks.

Seperti dijelaskan di atas, bahwa dengan cara kerja pelacuran langsung ditentukan dimana pertemuan antara pekerja seks dengan klien yang telah diatur oleh mucikari, ini memberikan keuntungan lain bahwa mucikari akan lebih mudah untuk memantau keselamatan pekerja seks dari tindakan klien yang melanggar persetujuan

1. Klien / pelanggan

a. Kehormatan (reputasi) lebih terjaga

b. Pelacuran online sangat bermanfaat bagi klien yang menggunakan jasa pekerja seks daripada klien yang harus datang ke lokalisasi pelacuran atau pekerja seks di jalanan karena dapat menjaga reputasi dan integritas rumah tangga untuk klien sehingga melalui pelacuran online akan tidak diketahui bahwa klien pribadi Suka menggunakan layanan pekerja seks.

c. Lebih banyak opsi pada tingkat yang diinginkan

d. Melalui prostitusi online memberikan keuntungan juga kepada klien bahwa ada tawaran layanan yang tersedia dari pekerja seks dan kriteria, fitur yang memenuhi keinginan klien yang dapat dilihat melalui situs yang telah tersedia 
sehingga melalui prostitusi online sebagai sarana untuk memenuhi kebutuhan klien.

\subsection{Kebijakan hukum pidana dalam pemberantasan kejahatan prostitusi online di Indonesia}

Pada dasarnya kebijakan pencegahan kejahatan prostitusi online adalah upaya publik untuk mencapai atau menciptakan ketertiban dengan bereaksi secara rasional terhadap modus prostitusi yang berubah karena kemajuan teknologi dalam memfasilitasi semua akses bagi masyarakat. Pemerintah Indonesia sudah memiliki alat legislasi dalam pemberantasan prostitusi online yang dikenal sebagai undangundang hukum pidana tetapi kejahatan ini terus berkembang. Berkembangnya kejahatan menemukan bahwa ada dua masalah utama dalam kebijakan kriminal dengan menggunakan kebijakan pidana (hukum pidana) yaitu tentang penentuan tindakan mana yang harus dilakukan sebagai tindakan kriminal dan sanksi apa yang harus digunakan atau dikenakan pada pelaku (Arief, 2014) .

Kedua isu sentral ini tidak dapat dipisahkan dari konsepsi integral kebijakan kriminal dan kebijakan sosial. Ini berarti bahwa solusi di atas harus diarahkan untuk mencapai tujuan spesifik dari kebijakan sosial-politik yang telah ditetapkan. Dengan kata lain, kebijakan hukum pidana juga termasuk dalam menyikapi dua isu sentral di atas, juga harus dilakukan dengan pendekatan yang berorientasi kebijakan. Barda Nawawi berpendapat bahwa pencegahan dan pencegahan kejahatan harus dilakukan dengan pendekatan integral dan ada keseimbangan antara hukuman dan non-hukuman. Kebijakan Penegakan Hukum Pidana 
(Kebijakan Penegakan Hukum Pidana), yang difungsikan melalui beberapa tahap seperti Tahap Perumusan (legislatif) kebijakan), Aplikasi (kebijakan peradilan) dan Eksekusi. (Kebijakan administratif). Dilihat dalam arti luas, kebijakan peradilan pidana dapat mencakup ruang lingkup kebijakan di bidang hukum pidana materiil, di bidang hukum pidana formal, dan di bidang eksekusi pidana. Secara garis besar, upaya untuk mengatasi kejahatan dabat dibagi menjadi dua, yaitu melalui "hukuman" (hukum pidana) seperti yang penulis jelaskan di atas dan melalui "nonpenal" (tidak / di luar hukum pidana). Menurut Hoefnagles, upaya pencegahan kejahatan dapat ditempuh dengan:

a. Penerapan aplikasi hukum pidana (aplikasi hukum pidana);

b. Pencegahan tanpa hukuman; dan

c. Mempengaruhi pandangan orang tentang kejahatan dan hukuman di media massa (mempengaruhi pandangan masyarakat tentang kejahatan dan hukuman / media massa). Upaya-upaya yang disebutkan oleh GP Hoefnagles di atas dalam huruf (b) dan (c) dapat dimasukkan dalam kelompok upaya "nonpenal" (Arief, 2014).

Terkait dengan kejahatan prostitusi online, batasan-batasan garis "hukuman" dan karenanya harus didukung oleh garis "nonpenal". Salah satu jalur "nonpenal" untuk mengatasi masalah sosial seperti yang disebutkan di atas adalah melalui jalur "kebijakan sosial". Kebijakan sosial adalah kebijakan atau upaya yang bersifat resesi untuk mencapai kesejahteraan masyarakat, kemudian 
berdasarkan uraian di atas pada butir $b$, pencegahan tanpa pidana adalah kebijakan hukum pidana non-pidana.

Lebih jelas lagi kebijakan hukum pidana nonpenal dalam memberantas kejahatan prostitusi online lebih merupakan tindakan pencegahan untuk terjadinya kejahatan, maka target utamanya adalah menangani faktor-faktor yang kondusif bagi terjadinya kejahatan. Faktor-faktor kondusif ini, antara lain, berpusat pada masalah atau kondisi sosial yang secara langsung atau tidak langsung dapat mengarah pada kejahatan. Dilihat dari perspektif politik kriminal secara makro dan global, tidak ada upaya pemasyarakatan yang menduduki posisi kunci dan strategis dalam mengatasi sebab dan kondisi kejahatan. Upaya kebijakan hukum non-pidana melalui penanaman masalah kesehatan mental masyarakat (higiene sosial), baik secara individu sebagai anggota masyarakat dan kesejahteraan keluarga, maupun masyarakat luas pada umumnya.

Jika dilihat dari penjelasan sebelumnya,pendidikan agama dan berbagai bentuk media pendidikan agama dalam memperkuat kepercayaan dan kemampuan orang untuk mengikuti jalan kebenaran dan kebaikan adalah peran yang sangat penting dan strategis. Pendidikan dan konseling agama yang efektif, tidak hanya diharapkan untuk membina jiwa manusia yang sehat tetapi juga membina keluarga yang sehat dan lingkungan sosial yang sehat. Ini berarti bahwa penanaman kesehatan masyarakat atau lingkungan sosial yang sehat (sebagai upaya tanpa hukuman dalam strategi politik kriminal) tidak boleh hanya berorientasi pada penggunaan agama tetapi juga berorientasi pada pendekatan identitas budaya nasional, dengan upaya- 
upaya berikut : tidak hanya diharapkan untuk membina jiwa manusia yang sehat tetapi juga membina keluarga yang sehat dan lingkungan sosial yang sehat. Ini berarti bahwa penanaman kesehatan masyarakat atau lingkungan sosial yang sehat (sebagai upaya tanpa hukuman dalam strategi politik kriminal) tidak boleh hanya berorientasi pada penggunaan agama tetapi juga berorientasi pada pendekatan identitas budaya nasional, dengan upaya-upaya berikut:tidak hanya diharapkan untuk membina jiwa manusia yang sehat tetapi juga membina keluarga yang sehat dan lingkungan sosial yang sehat.

Ini berarti bahwa penanaman kesehatan masyarakat atau lingkungan sosial yang sehat (sebagai upaya tanpa hukuman dalam strategi politik kriminal) tidak boleh hanya berorientasi pada penggunaan agama tetapi juga berorientasi pada pendekatan identitas budaya nasional, dengan upaya-upaya berikut:

a. Memberikan pendidikan seks seperti pendidikan internet di sekolah-sekolah yang mencakup penggunaan internet yang efektif, terutama di bidang pengembangan ilmiah

b. Melakukan kegiatan positif \& berdoa kepada Tuhan

c. Memiliki hubungan dekat antara orang tua dan anak

d. Memonitor asosiasi \& memilih lingkungan yang positif

e. Mengambil peran pemerintah yang tegas tetapi bersinergi dalam mengambil kebijakan

\section{Kesimpulan}


Pelacuran online terus berkembang di Indonesia meskipun pemerintah Indonesia telah melakukan upaya hukuman dalam bentuk memiliki legislasi yaitu KUHP tentang Hukum Pidana, Hukum Nomor 39 Tahun 1999 tentang Hak Asasi Manusia, Undang-Undang Republik Indonesia Nomor 21 Tahun 2007 Tentang Penghapusan Kejahatan Perdagangan Orang, Undang-undang Republik Indonesia Nomor44 Tahun 2008 Tentang Pornografi, Undang-Undang Republik Indonesia Nomor 19 Tahun 2016 Tentang Amandemen Undang-Undang Nomor 14 Tahun 2008 tentang informasi dan transaksi elektronik karena kebijakan pemerintah Indonesia yaitu Indonesia bersih posrtitusi dan lokalisasi tahun 2019.

Kebijakan pemerintah ini tidak hanya membuat banyak sekali lokalisasi yang ditutup paksa tetapi juga para pekerja seks. PSK diberikan pesangon dan pekerjaan baru, hal ini positif sepanjang PSK memiliki keinginan untuk berubah. Selanjutnya upaya pemerintah Indonesia adalah menutup situs porno tetapi kenyataannya hari ini ditutup besok menggandakan situs yang menawarkan layanan pelacuran yang sama. Sehingga ditemukan keterbatasan dari hukum pidana, karenanya diperlukan kebijakan hukum non-pidana sebagai media pendidikan agama dalam memperkuat kepercayaan dan kemampuan manusia untuk mengikuti jalan kebenaran dan kebaikan peran yang sangat penting dan strategis.

\section{Saran}

Pendidikan agama dan moral yang efektif pendidikan keterampilan lifeskill dan konseling, tidak hanya diharapkan untuk membangun pribadi manusia yang sehat tetapi juga untuk berpromosi keluarga yang sehat dan lingkungan sosial yang sehat 
dengan kata lain pemerintah berusaha memberikan bekal keahlian yang membuat PSK melirik atau setidaknya membuat mereka mampu mencari nafkah dengan caracara yang baik. Selain itu juga sebagai upaya promosi kesehatan masyarakat atau kesehatan sosial melalui upaya memberikan pendidikan seks yang tepat, Kegiatan Positif \& lebih dekat dengan Tuhan, menjalin hubungan intim hubungan antara orang tua dan anak-anak memonitor pergaulan \& Memilih lingkungan yang positif dan mensinergikan peran penentu pemerintah tetapi bersinergi dalam mengambil kebijakan.

\section{Referensi}

Alam, A.S, Pelacuran dan Pemerasan, Studi Sosiologi Tentang Eksploitasi Manusia oleh Manusia, Bandung: Alumni, 1984.

Amiruddin. (2012). Pengantar metode penelitian hukum. Jakarta: PT. RajaGrafindo Persada.

Anwar, Y., \& Andang. (2010). Kriminologi. Bandung: Refeleksi Aditama.

Arief, B.N. (2014). Kebijakan hukum pidana (Perkembangan Penyusunan konsep KUHP baru). Semarang: Grup Prenadamedia.

Dewi, Heriana Eka, Memahami Perkembangan Fisik Remaja, Yogyakarta : Gosyen Publishing, 2012.

Efendi, Masyhur, Dimensi/Dinamika Hak Asasi Manusia dalam Hukum Nasional dan international, Jakarta: Ghalia Indonesia, 1994.

Huijbers, Teo, Filsafat Hukum, Yogyakarta: Kanisius, 1995.

Ilyas, A. (2012). Asas-asas hukum pidana, memenangkan hukuman dan pertanggungjawaban pidana sebagai persyaratan pemidanaan. Yogyakarta: Offset Mahakarya Rangkang.

Kartono, K. (2013). Patologi sosial. Jakarta: Rajawali Pers. 
Pound, Roscoe, Pengantar Filsafat Hukum, Diterjemahkan oleh Muhammad Radjab, Jakarta: Bhratara Karya Aksara,1982.

Ridwan, H.R., Hukum Administrasi Negara, Jakarta: Raja Grafndo Persada, 2006.

Saptari, Ratna dan Brigitte Holzner, Perempuan Kerja dan Perubahan Sosial Sebuah Pengantar Studi Perempuan, Jakarta: Kalyanamitra, 1997.

Sianturi, S.R, Asas-asas Hukum Pidana Indonesia dan Penerapanya, Cet. IV, Jakarta: Alumni AhaemPeteheam, 1996.

Simandjuntak, Patologi Sosial, Bandung: Tarsito, 1985.

Sitompul, Asril, Hukum Internet Pengenalan mengenai Masalah Hukum di Cyberspace, Bandung: Citra Aditya Bakti, 2004.

Sutarman, Cyber Crime Modus Operandi dan Penanggulangannya, Yogyakarta: LaksBang PRESSindo, 2007.

Sutrisna, I Gusti Bagus, "Peranan Keterangan Ahli dalam Perkara Pidana (Tijauan terhadap pasal 44 KUHP),"dalam Andi Hamzah (ed.), Bunga Rampai Hukum Pidana dan Acara Pidana, Jakarta: Ghalia Indonesia, 1986.

Simandjuntak, S. (2012). Patologi sosial. Bandung: Tarsito.

Suzanalisa. (2012). Metodologi penelitian hukum. Jambi: Fakultas Hukum Universitas Batanghari.

UUD 1945 sebagai dasar Negara Indonesia Hukum Pidana Hukum Pidana

Undang-Undang Nomor 39 Tahun 1999 tentang Hak Asasi Manusia

Undang-Undang Republik Indonesia Nomor 21 Tahun 2007 Tentang Pemberantasan Tindak Pidana Perdagangan Orang,

Undang-Undang Republik Indonesia Nomor 44 Tahun 2008 tentang Pornografi

Undang-Undang Republik Indonesia Nomor 19 Tahun 2016 Tentang Perubahan atas Undang-Undang Nomor 14 Tahun 2008 tentang informasi dan transaksi elektronik . 